\title{
UPDATE CHAPTER \\ ENGLISH LANGUAGE LEARNING USING SOCIAL MEDIA
}

\author{
Evi Mahsunah \\ Email: evimahsunahtaman@yahoo.com \\ Universitas Nahdlatul Ulama Sidoarjo \\ Sidoarjo, Indonesia
}

\begin{abstract}
This study explores the changing students' habit update status in social media into update chapter to increase their achievement in English. It is a learning strategy in English language teaching and learning using social media technology. The aim is to motivate students more active to read their literature and then share and discuss their reading in social media. The students not only have to update their chapter in reading, but also have to give comment or respond to their friends update. So, this strategy makes the students discuss their lesson more than usual. This study uses questioner and documentation technic to collect the data. Based on the data, it is known that students are already using social media for purposes that include the social and the educational. Update chapter make them using this technology in class/after class. Social media brings learning outside the classroom autonomous, independent, motivational and fun. Therefore, the students'achievement in English language teaching and learning also increases significant.
\end{abstract}

Keywords: Update, learning strategy, social media

\section{INTRODUCTION}

In recent years social media has a very important role and becomes a predominant factor in our daily live, millions of people now use social media to interact, collaborate, network, or entertain themselves. Especially among young people, who 'hang out' on 
Facebook or Twitter via their laptops or mobile devices almost around the clock. They update their status on usual or unusual events in their lives. The practicality and variety of facilities offered by social media is an attraction that attracts people to continue to use it, because it can serve as a means of cheap, fast, and easy communication.

Similar phenomena also occur in the Nahdlatul Ulama Sidoarjo University, social media has become part of the daily life of students. We can see the students open some social media like Facebook, BBM, WhatsApp and Twitter to update their status or just read their friend's status or the news that their friend wrote every time and everywhere. They spend more their time for social media. This is also stated by Arsyad (2013: 195), according to him now comes the social media, where we can know the status of people around the world on the real time. Otherwise, it is almost less than fifty percent of students who spend their times to open or read their literatures. Most of students like reading their friends update better than reading their literatures.

Based on this phenomenon, where students waste their time in enjoying social media only for chatting, playing games, or updating status, it is better if the teachers or educators able to utilize social media to support their teaching-learning activities, because it can be used for media to facilitate the students in better learning. Teachers/ educators do not only teach the language skills and language components separately, but also teach the student about skills of life and characters. In this technology era, teachers have to be more creative and innovative in using instructional media for the teaching and learning process.

Students who get used to high technology gadgets in their daily life will find the learning boring if the teachers still use monotonous ways of teaching. It is supported by Ian Fordham et.al (2013: 2) affirms that social media such as Facebook is in an excellent position to support the way young people, teachers and other educators collaborate, access and curate new learning. Therefore, the researcher creates a new term in learning strategy, it is called update chapter. The term is adapted from the social media term update status. So, update chapter can be defined as keep posted/ information about students 'understanding in learning process. 
Regarding to the students' habit who continuously update status on social media, this study is conducted to change their habit update status into update chapter to increase their achievement in English. It is a learning strategy in English language teaching and learning using social media technology. The aim is to motivate students more active to read their literatures and then share and discuss their reading in social media. In this case, the students not only have to update their chapter in reading, but also have to give comment or respond to their friends update. So, this strategy makes the students discuss their lesson more than usual. Furthermore, they may use their mobile devices to support their study maximally.

\section{METHOD}

This study focuses on the Fifth and the Third semester students from English Education Study Program, Teacher Training and education Faculty Nahdlatul Ulama Sidoarjo University as target respondents. This study uses questioner and documentation technic to collect the data, and then, the data are analyzed using coding technic. There are about 34 respondents, all of them have to explain their respond and opinion related to the learning process of Semantics and Introduction to Literature subjects using update chapter in social media. For example, how many hours in a day they read their books/ literatures, how many times they update their chapter in social media, and how often they give comment of their friends "update.

There are several kinds of popular social media applications in the students' smartphone, such as; Twitter, Face book, Line, and Whats app. Nevertheless, this study focuses on face book and whats app application because based on the survey, both of face book and whats app are used by more than eighty percent students in Nahdlatul Ulama Sidoarjo University.

\section{FINDING}

The respondents of this study are the Fifth and the Third semester students from English Education Study Program Nahdlatul Ulama Sidoarjo University; they are about 19 up to 21 years old and active using face book and whats app in their daily activity. Update 
chapter make them using this technology in class or after class. Social media brings learning outside the classroom autonomous, independent, motivational and fun.

\section{Using Update Chapter in Social media}

The respondents are classified into three groups; they are super active user, active user and passive user. The writer asked to the students in the questionnaire about how often students use or open their face book or whats app accounts daily. It is discovered that more than 50\% respondents are super active user, 32\% are active user, and $15 \%$ respondents are passive user.

The data showed that super active user of social media is the user who open face book and whats app as a learning media more than 10 times in a day. Almost 53 percent respondents (18 respondents) are super active user of social media. They said that they open these social media face book and whats app group discussion around the clock or more than three hours in a day. They use them to update their chapter, get more information related to the topic discussion, read their friends' update and then give comment or just for sharing the News. They update their chapter by writing a paragraph, summary, the theory from the book references or write their own opinion on their walls, and then their friends read and give comments on their update. Moreover, there are ten respondents said that they always read their literatures before update chapter or give comment on their friends status.

The second group is active user of social media; there are about 32 percent or 11 respondents from this group. They active open these social media for learning in their spare time or less than 10 times in a day. They update their chapter in a group, read their friends' update and give comments after reading their literature.

The last group is passive user of social media; there are about 15 percent or 5 respondents from this group. They only open their group discussion to know or read their friends update chapter, but they do not active update their chapter although they read their literatures regularly. Passive users open face book and whatsapp group discussion not more than five times in a day. 


\section{Impact of Update chapter in Social Media on Academic Achievement}

Considering the impact of using update chapter in social media in English subjects to the better result in their academic achievement, 67\% agree and $18 \%$ of the students strongly agree with it. But when the writer asked deeper to the two subjects that they took, the writer gets variety of answers. For the Semantics subject, $58 \%$ students agree that their learning result is represented by their update chapter habits while $11 \%$ strongly agree about this statement. $63 \%$ students agree and 14\% strongly agree that their Introduction to Literature results are represented by their update chapter habits. The questionnaire results are indicating that some students see large correlation between their academic achievement and their update chapter habits.

\section{DISCUSSION}

In this study, students drove the learning more enjoyable because they learned with their abilities and preference for using different type of media. In other side, students constructed to pursue in comprehending about what they read in wall Facebook group by update chapter. The students competed with other students to answer the questions from the lectures or to give comment on their friend's update. It was passive and active students can be involved together in the reading activities in Facebook Group or whats app group. It is supported by Ian Fordham et.al (2013: 2) stated that Facebook is in an excellent position to support the way young people, teachers and other educators collaborate, access and curate new learning.

Regarding to the data finding, it can be said that there is a high level of social media usage in English Education Study Program, Teacher Training and education Faculty Nahdlatul Ulama Sidoarjo University. Most of the respondents are super active or active in using social media face book and whats app on their learning process. They write their opinion and sharing their reading on social media's group discussion regularly, they become more confident to write their expression in English. It is very different with the situation in the class 
discussion where not more than $30 \%$ of the students in the class who active to give comment or sharing their idea.

These phenomena may be caused by the condition where learning discussion on social media is more flexibility and relax than face to face interactions. Students don't face same turn-taking constraints: opportunities to have floor are balanced and visual record of language interaction helps them negotiate meaning. Choices made in online interactions encourage future participation because online "conversations" are different in some ways, social media provide excellent models for how language is actually used. Students see authentic language ranging from casual conversation to academic discourse.

On the other hand, there are several disadvantages of Facebook as a learning tool, such as: privacy issues, distractive multitasking while using FB, lack of access in schools, sentiment amongst students (and parents) that FB is a place to socialize, separate from academic work (Hew 2011) - separation between 'pleasure' (socializing) and 'pain' (learning), students may consider Facebook to be more of a "social study space" that is off limits to teachers difficulties in attempts to formalize the use of Facebook in the classroom (Gray et al., 2010).

Therefore, the teachers or lecturers have to make rules or learning contract with the students before they use social media in the teaching and learning process. It used to prevent unexpected condition such as students may post inappropriate or off-topic videos, photos, posts, tweets, or students may post inappropriate or derogatory comments on others' posts. Then, setting up or create a Facebook or whats app group before each course, putting up announcements such as text, hyperlinks, pictures and videos on Wall and allows the students or participants to share resources or get feedback from others.

\section{CONCLUSION}

Update chapter in Social media motivates students to read their literatures and help them to be active in English writing. They become more confident to write their expression, opinion and sharing their reading on social media's group discussion regularly. Social media 
brings learning inside/outside the classroom autonomous, independent, motivational and fun, they turn out to be used their gadgets to support their study maximally. Therefore, the students' achievement in English language teaching and learning also increase significant. This study suggests the use of social media in teaching and learning process must be encouraged as the education tool and can be positive proper to engage students as modern learner.

\section{REFERENCES}

Arsyad, A. (2013). Media Pembelajaran. Jakarta: PT Raja Grafindo.

Benthaus, J., Pahlke, I., Beck, R. \& Seebach, C. (2013). Improving Sensing and Seizing Capabilities of a Firm By Measuring Corporate Reputation Based on Social Media Data. Proceedings of the 21st European Conference on Information Systems IMPRO, 1-12.

Boyd, D. M. \& Ellison, N. B., 2007. Social Networking Sites: Definition, History, and Scholarship. Journal of ComputerMediated Communication, 13(1), 10-230.

Gray, K., Annabell, L., \& Kennedy, G. (2010). Medical students' Use of Facebook to Support Learning: Insights from Four Case Studies. Medical Teacher, 32, 971-976.

Hew, K. F. (2011). Students' and Teachers' Use of Facebook. Computers in Human Behavior, 27, pp. 662-676.

Kaplan, A. M. \& Haenlein, M. (2010). Users of the world, unite! The challenges and opportunities of Social Media. Business Horizons, 53(1), 59-68.

Kirkwood, A. \& Price, L. (2014). Technology-enhanced learning and teaching in higher education: what is 'enhanced'and how do we know? A critical literature review. Learning, Media and Technology, 39(1), 636. 